\title{
Efficiency of metabolizable energy utilization for maintenance and gain and evaluation of Small Ruminant Nutrition System model in Santa Ines sheep
}

\author{
José Gilson Louzada Regadas Filho ${ }^{1}$, Elzânia Sales Pereira ${ }^{1}$, Arturo Bernardo Selaive \\ Villarroel $^{1}$, Patrícia Guimarães Pimentel ${ }^{1}$, Rildson Melo Fontenele ${ }^{1}$, Marcus Roberto Góes \\ Ferreira Costa ${ }^{1}$, lana Sérvulo Gomes Maia ${ }^{1}$, Weberte Alan Sombra ${ }^{1}$ \\ ${ }^{1}$ Departamento de Zootecnia, Universidade Federal do Ceará - UFC, 60020-181, CE, Brazil.
}

ABSTRACT - This study was carried out to estimate efficiencies of the utilization of metabolizable energy for maintenance $\left(\mathrm{k}_{\mathrm{m}}\right)$ and weight gain $\left(\mathrm{k}_{\mathrm{g}}\right)$ and to evaluate the Small Ruminant Nutrition System (SRNS) model in predicting dry matter intake and average daily gain of growing Santa Ines sheep. Twenty-four non-castrated Santa Ines sheep, at 50 days of age and with average body weight of $13.00 \pm 0.56 \mathrm{~kg}$, respectively, were used. After a 10-day adaptation period, four animals were slaughtered to be used as reference for estimating initial empty body weight and body composition of the other animals. The remaining animals were distributed in a random block design, with the treatments consisting of diets containing different levels of metabolizable energy $(2.08,2.28,2.47$ and $2.69 \mathrm{Mcal} / \mathrm{kg}$ of DM), with five replicates. The metabolizable energy use efficiencies for maintenance and for weight gain were calculated from the relationship between the dietary net energy for maintenance and gain and ME concentration in the diets. Evaluation of the SRNS model was performed by adjustment of simple linear regression model between the predicted (independent variable) and observed (dependent variable) values. The estimated energy use efficiency for maintenance $\left(\mathrm{k}_{\mathrm{m}}\right)$ was 0.70 ; and for gain weight $(\mathrm{kg})$ it showed to be inversely proportional to the increase of metabolizable energy concentration in the diet. The dry matter intake predicted by the SRNS model did not statistically differ from that observed, but the model overestimated the average daily gain by $5.18 \%$. Those results can contribute to the construction of a database, which could be condensed into several others in a predictive model of performance and feed planning for sheep reared in Brazil.

Key Words: mechanistic model, nutritional requirements, semiarid

\section{Introduction}

The knowledge of how the animal uses the metabolizable energy (ME) for its metabolic functions is extremely important, since this efficiency varies according to the physiological function (maintenance, gain, pregnancy etc), and to the concentration of ME in the diet. It also varies among determination methodologies and among systems of feed evaluation and nutrient requirements. From the knowledge of net requirements and considering the factors of use efficiency of metabolizable energy of feed for maintenance $\left(\mathrm{k}_{\mathrm{m}}\right)$ and gain $\left(\mathrm{k}_{\mathrm{g}}\right)$, energy dietary requirements can be obtained.

Mechanistic models for feed and nutritional requirement assessment have been developed over the past 20 years in order to compile the knowledge developed in the area of nutrition and thus to observe gaps of knowledge in this area. Several models predict animal response from feed, climate and animal inputs. Among them, the model Cornell Net Carbohydrate and Protein System - Sheep (CNCPS-S)
(Cannas et al., 2004) and more recently, Small Ruminant Nutrition System (SRNS) (Tedeschi et al., 2010) stand out. The latter is a modification of CNCPS-S to include the latest information, in addition to a sub-model for nutrition of goats.

These models use mechanistic tools to estimate the nutritional requirements of sheep, and the biological value of feed used for this species. However, these models are usually developed in studies with wool sheep with aptitudes and climate different from those found in production systems in the Brazilian semiarid region, where the largest sheep flock in the country is found, a fact that makes evaluation of these models under those conditions necessary.

Thus, the objectives of this study were to estimate use efficiency of metabolizable energy for maintenance and weight gain and to evaluate the predictions of dry matter intake and average daily gain by the nutritional model Small Ruminant Nutrition System (SRNS) in growing Santa Ines sheep. 


\section{Material and Methods}

The experiment was conducted in Departamento de Zootecnia of the Universidade Federal do Ceará. Twentyfour non-castrated Santa Ines lambs, with average body weight (BW) and standard error of the initial mean of $13.00 \pm 0.56 \mathrm{~kg}$ and at approximately 50 days of age were used. Firstly, animals were identified with earrings, weighed, wormed and distributed into individual stalls equipped with troughs for the supply of feed and water ad libitum.

After a 10-day adaptation period, four animals were selected randomly and slaughtered to be reference for estimates of empty body weight (EBW) and initial body composition of the 20 remaining animals. These animals were then distributed in a random block design (homogeneous weights) with four treatments, consisting of diets formulated with each one of the levels of the evaluating metabolizable energy (2.08, 2.28, 2.47 and $2.69 \mathrm{Mcal} / \mathrm{kg} \mathrm{DM})$, obtained from different roughage:concentrate relations: 75:25; 62.5:37.5, 50:50, and 37.5:62.5 with five replications.

The experimental diets were formulated according to NRC (1985), composed of ground Tifton 85 (Cynodon sp.) hay, soybean meal, corn meal, sodium chloride, urea, limestone, dicalcium phosphate and mineral premix (Tables 1 and 2).

Diets were fed once daily at 7 a.m., and adjusted daily for about $20 \%$ of leftovers. Before morning supply, leftovers from each experimental unit were collected, which after being weighed, recorded and sampled, were stored in a freezer $\left(-10^{\circ} \mathrm{C}\right)$ together with samples of hay and concentrates, subsequently forming a weekly composite sample per animal, which, at the end of the experiment period, formed a total composite sample per animal/diet.

Table 1 - Chemical composition of the ingredients

\begin{tabular}{|c|c|c|c|c|c|c|c|}
\hline Nutrient & Hay & Corn & Soybean & Conc. 1 & Conc. 2 & Conc. 3 & Conc. 4 \\
\hline Dry matter $(\% \mathrm{NM})$ & 92.73 & 91.44 & 92.54 & 90.30 & 90.18 & 90.94 & 90.30 \\
\hline Mineral matter (\%DM) & 6.03 & 1.74 & 6.84 & 3.53 & 3.76 & 3.56 & 3.71 \\
\hline Crude protein (\%DM) & 9.94 & 9.39 & 44.05 & 21.14 & 21.72 & 22.00 & 22.27 \\
\hline Neutral detergent fiber (\%DM) & 75.03 & 14.78 & 15.78 & 15.91 & 15.15 & 16.01 & 14.87 \\
\hline Acid detergent fiber (\%DM) & 36.32 & 4.78 & 9.24 & 5.63 & 5.67 & 2.70 & 5.83 \\
\hline NDFap (\%DM) & 67.91 & 12.76 & 13.74 & 14.16 & 13.72 & 14.61 & 13.45 \\
\hline
\end{tabular}

Conc. $=$ Concentrate.

Table 2 - Percentage and chemical composition of experimental diets

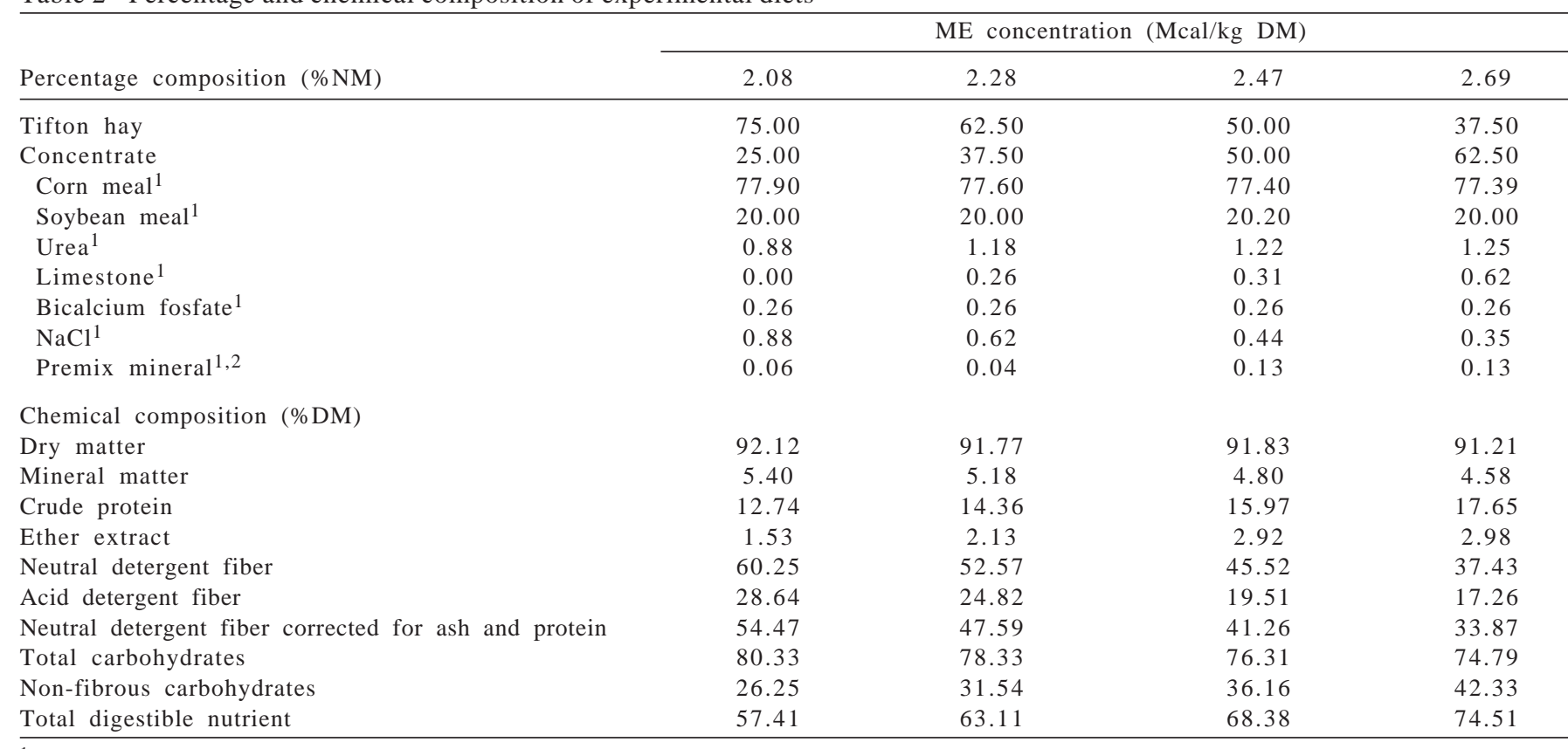

1 Centesimal composition regarding the diet concentrate portion.

${ }^{2}$ Composition: calcium - 7.5\%; phosphorus - 3\%; iron - 16,500 ppm; manganese - 9,750 ppm; zinc - 35,000 ppm; iodine - 1,000 ppm; selenium - 225 ppm; cobalt - 1,000 ppm. 
Afterwards, samples were thawed, homogenized and milled in a Wiley mill equipped with a 1-mm mesh sieve, and then analyzed for contents of dry matter (DM), mineral matter (MM), organic matter (OM), crude protein (CP), ether extract (EE), acid detergent fiber (ADF) and gross energy (GE) following the protocols described by Silva \& Queiroz (2002). The analysis of neutral detergent fiber (NDF) was carried out according to Mertens (2002) without the use of sodium sulfite and corrected for ash and nitrogen compounds (NDFap), as proposed by Mertens (2002) and Licitra et al. (1996), respectively.

Total carbohydrate (TC) was calculated by using the expression: TC $(\%)=100$ - (\% CP +\% EE +\% MM) (Sniffen et al., 1992). Non-fibrous carbohydrates (NFC) were calculated as: NFC (\%) = 100 - (\% NDFap +\% CP +\% EE +\% MM) (Weiss, 1999). For concentrates, due to the presence of urea in their constitution, content of NFC was according to an adaptation of the equation proposed by Hall (2000), and NFC $=100-[(\%$ CP - \% CP derived from urea $+\%$ urea $)$ $+\%$ NDFap +\% EE +\% ash]

Animals were weighed weekly to monitor the average daily gain (ADG), and when the average $B W$ of the treatment reached $28 \mathrm{~kg}$, they were slaughtered. At that time, an animal in the group with the lowest energy concentration in feed was also slaughtered (animals placed in the treatment with $2.08 \mathrm{Mcal} / \mathrm{kg} \mathrm{DM}$ of ME). Thus, it was preceded to each group until all animals were slaughtered.

Before slaughter, animals were weighed, subjected to solids and water fast for 18 hours and weighed again for obtention of body weight during fasting (BWF). After slaughter and blood collection, skinning and gutting of the animal were carried out. The gastrointestinal tract was weighed full and then emptied, washed and left to drain; it was weighed again with the weight of organs and other body parts (carcass, head, leather, blood, feet and tail), then empty body weight (EBW) was obtained.

All organs (reproductive system, trachea + lungs + tail + esophagus, liver, heart, kidneys, spleen, bladder, omasum, abomasum, rumen + reticulum, diaphragm, small and large intestine, omental, perirenal, mesenteric and heart fat) plus head were weighed and frozen. The blood collected at slaughter was weighed and placed to dry in a forced ventilation oven at $55{ }^{\circ} \mathrm{C}$ for 72 hours, and then ground for further analysis of the content of dry matter, nitrogen and ether extract. Paws were sampled (front and right hind paws) and the leather was cut into strips and sampled for further analysis. Subsequently, the carcass of each animal was cooled for 24 hours at $5{ }^{\circ} \mathrm{C}$ and then cut on a band saw in order to use the right side carcass for determination of chemical composition.
After that, the half-carcass, organs and leather samples were ground in industrial meat grinder and homogenized. The organ ground mass was divided by two and homogenized with the ground mass of the right half-carcass and legs. These samples, along with the leather samples, were dehydrated in a forced air oven at $55{ }^{\circ} \mathrm{C}$ for 72 hours and then stored. Subsequently, samples were taken to an oven at $105{ }^{\circ} \mathrm{C}$ for 24 hours to obtain the fat dry matter content (FDM). Next, they were processed in a multiprocessor and defatted to obtain the defatted dry matter (DDM), and then analyzed for contents of total nitrogen (TN).

To determine the value of total digestible nutrients (TDN), metabolizable energy and metabolizability (qm) of experimental diets, a digestibility trial was performed in metabolic cages using 16 non-castrated Santa Ines sheep, with about $28 \mathrm{~kg}$ of BW, distributed in a random block design (homogeneous weights) with four treatments (experimental diets) and four replications. The experiment lasted 17 days, 10 days for adaptation to the diets and to the cages and seven days for collection of samples of feed provided and leftovers, and fecal total collection. Feed samples, concentrated diets, feces and leftovers were frozen and later processed and analyzed as mentioned earlier. Total digestible nutrients were calculated according to Weiss (1999): TDN = CPd + NFCd + NDFapd + EEd + 2.25, and CPd, NFCd, NDFapd and EEd corresponded to: digestible crude protein, digestible non-fibrous carbohydrates, digestible neutral detergent fiber corrected for ash and protein and digestible ether extract, respectively.

It was considered that $1 \mathrm{~kg}$ TDN contains $4.409 \mathrm{Mcal}$ of digestible energy, and to estimate the metabolizable energy of diets, the value of $82 \%$ of digestible energy was considered (NRC, 1996). The metabolizability (qm) was calculated as: $\mathrm{qm}=\mathrm{ME} / \mathrm{GE}$ for each experimental diet (AFRC, 1993).

The net requirement of protein for maintenance and gain was obtained from Regadas Filho (2011b) and net energy requirement for maintenance and gain from Regadas Filho (2011a), where the nonlinear form of the model employed by Lofgreen and Garrett (1968) was used to describe the heat production at zero intake of metabolizable energy. The $\mathrm{k}_{\mathrm{m}}$ was estimated from the interactive method, in which the balance between heat production and metabolizable energy intake was obtained.

The concentrations of dietary net energy were calculated according to Harris (1970). Dry matter intake to maintain energy balance was calculated by dividing the metabolizable energy requirement for maintenance (MEm) by the concentration of the dietary ME, with MEm as the relationship between net energy for maintenance (NEm) divided by the metabolizability found by interactive 
method. The concentration of net energy of each diet for maintenance (NEmd) was obtained by dividing the heat production in fasting by DMI to maintain the energy balance expressed in $\mathrm{g} \mathrm{DM} / \mathrm{kg} \mathrm{EBW}^{0.75} /$ day, whereas the DMI over the maintenance needs was obtained by subtracting the DM intake sufficient for energy balance (g DM $/ \mathrm{kg} \mathrm{EBW}^{0.75}$ ) for each diet from the total DM intake (g DM/kg EBW ${ }^{0.75}$ ). The concentration of net energy for gain of each diet (NEgd) was calculated by dividing the energy retained per day (kcal/kg EBW ${ }^{0.75}$ ) by DM intake above maintenance needs, expressed in g DM/kg EBW ${ }^{0.75}$.

Efficiencies of metabolizable energy for maintenance and weight gain were also estimated from the equations recommended by AFRC (1993):

$$
\begin{aligned}
& k_{m}=0.503+0.35 \times q m \\
& k_{g}=0.006+0.78 \times q m \\
& q m=M E / G E
\end{aligned}
$$

To express the metabolizable protein requirements, efficiencies of metabolizable protein for maintenance ( $\mathrm{kpm}$ ) and gain (kpg) equal to 1 and 0.59 , respectively, were taken (AFRC, 1993).

For conversion of metabolizable protein requirement into crude protein, due to lack of data with sheep, this study used the equations adopted by Marcondes et al. (2010) for cattle.

To evaluate the SRNS model, the inputs referring to each animal individually like, for example, BW and DMI observed and also data on the chemical composition of diets and environmental conditions were used.

The SRNS model was evaluated as for its precision using Pearson's coefficient correlation ( $\mathrm{r}$ ) and as for its accuracy by adjusting the linear regression equation between predicted (independent variable) and observed (dependent variable) values. The equation parameters were tested together on the following hypothesis by $\mathrm{F}$ test:

$$
\begin{aligned}
& H_{o}: \beta_{o}=0, \beta_{1}=1 \\
& H_{A}: \operatorname{not} H_{o}
\end{aligned}
$$

For the non-rejection of the null hypothesis, the model was sensitive in predicting animal responses.

Adjustment of linear regression equations was done by using PROC REG routine and Pearson's coefficient correlation was adjusted through PROC CORR (SAS 9.0) $(\alpha=0.05)$.

\section{Results and Discussion}

Considering the equation: $H P=61.50(4.56) \exp ^{(0.004}$ $(0.0002) * \mathrm{MEI})$, and using the interactive method, the value at the point where the heat production was equal to the metabolizable energy intake of $87.23 \mathrm{kcal} / \mathrm{kg} \mathrm{EBW}^{0.75} /$ day is equal to the metabolizable energy requirement for maintenance.

By using the methodology proposed by Harris (1970), a $\mathrm{k}_{\mathrm{m}}$ value of 0.70 was observed when the relationship between NEm/MEm is used, with MEm determined by the interactive method, i.e., $61.50 / 87.23=0.70$. This value is higher than that recommended by the SRNS, 0.644.

Employing the equation of AFRC (1993), which suggests variable $\mathrm{k}_{\mathrm{m}}$ and estimated from the metabolizability (qm) of the diet, the values from 0.68 to 0.73 were found for diets with ME concentrations of 2.08 to $2.69 \mathrm{Mcal} / \mathrm{kg} \mathrm{DM}$, respectively, and average efficiency 0.70 , equal to the values obtained in this research.

Use efficiency of ME for gain $\left(\mathrm{k}_{\mathrm{g}}\right)$ presented itself inversely proportional to the concentration of $\mathrm{ME}$ in the diet, ranging from 0.62 to 0.30 for diets containing 2.08 to $2.69 \mathrm{Mcal} / \mathrm{kg} \mathrm{DM}$, respectively (Table 3), a behavior also reported by Alves et al. (2008) in studies with Moxotó goats.

According to Garrett (1980), a efficiency of energy metabolizable for gain is directly related to the composition

\begin{tabular}{|c|c|c|c|c|}
\hline \multirow[t]{2}{*}{ Variable } & \multicolumn{4}{|c|}{ Dietary metabolizable energy (Mcal/kg DM) } \\
\hline & 2.08 & 2.28 & 2.47 & 2.69 \\
\hline Gross energy (Mcal/kg DM) & 4.07 & 4.11 & 4.20 & 4.15 \\
\hline Maintenance DMI (g/kg EBW $\left.{ }^{0.75}\right)$ & 41.94 & 38.26 & 35.32 & 32.43 \\
\hline Gain DMI (g/kg EBW $\left.{ }^{0.75}\right)$ & 39.79 & 49.11 & 62.79 & 91.67 \\
\hline NEm (Mcal/kg DM) & 1.47 & 1.61 & 1.74 & 1.90 \\
\hline $\mathrm{k}_{\mathrm{m}}^{2}$ & 0.70 & 0.70 & 0.70 & 0.70 \\
\hline $\mathrm{kg}^{2}$ & 0.62 & 0.42 & 0.37 & 0.30 \\
\hline $\mathrm{k}_{\mathrm{m}}^{3}$ & 0.68 & 0.70 & 0.71 & 0.73 \\
\hline $\mathrm{k}_{\mathrm{g}} \mathrm{m}^{3}$ & 0.40 & 0.44 & 0.46 & 0.51 \\
\hline
\end{tabular}
of gain. Although fat retains more quantity of energy, its deposition efficiency is higher than efficiency for protein deposition (Geay, 1984) and this is related to the fact that

Table 3 - Energy values of diets and use efficiencies of metabolizable energy in growing Santa Ines sheep 
the process of synthesis and degradation (turnover) of body protein reduces the energy efficiency of their accumulation; however, the deposition of fat at high levels, as observed in this study (early animals) (Regadas Filho et al., 2011b) can reduce the overall efficiency of use of metabolizable energy for gain, due to the high energy requirement for gain of the same amount of body mass compared with late animals.

The high fat deposition shows within a needed biological logic, inasmuch as animals adapted to regions where the seasonality of feed/energy is extremely high, body stores like fat are essential for maintenance of the life of these animals under these conditions. Moreover, the animals used in this study showed low genetic merit, which characterizes Santa Ines sheep reared extensively in the Brazilian semiarid region, a factor that may also explain the decrease in efficiency energy metabolizable for gain.

Using the AFRC equation, $\mathrm{a}_{\mathrm{g}}$ increase was observed when there was greater concentration of the diet ME (Table 3) is noticed, which was expected due to the linearity of the $\mathrm{k}_{\mathrm{g}}$ predicting equation from qm.

Compiling data from energy requirements for maintenance and weight gain obtained by Regadas Filho et al. (2011a) and by using $\mathrm{k}_{\mathrm{m}}$ value of $0.70 \mathrm{k}_{\mathrm{m}}$ and $\mathrm{k}_{\mathrm{g}}$ average value of 0.43 for those functions obtained in this research, the nutritional requirements of growing Santa Ines sheep at different body weights and daily weight gains in order to facilitate the use in diet formulation are obtained (Table 4). For converting metabolizable energy requirement into digestible energy requirements, the factor of 0.82 was used, and for conversion into TDN requirement, the factor 4.409 Mcal DE/kg TDN was used (NRC, 1996).

Total dietary energy requirements increased with the addition of BW within the same gain range (Table 4). Digestible energy requirement of a $20 \mathrm{~kg}$ BW sheep gaining $200 \mathrm{~g} /$ day was $2.45 \mathrm{Mcal} /$ day or $556 \mathrm{~g}$ TDN/day, which is about $18 \%$ lower than that recommended by NRC (2007), $660 \mathrm{~g} /$ day. It must be said that the $0.43 \mathrm{~kg}$ used was the average dietary value, which can be changed according to the concentration of metabolizable energy in the diet.

The protein requirements for maintenance and weight gain (Regadas Filho et al., 2011b) of Santa Ines sheep with different body weights and daily weight gains is also compiled (Table 5). The total metabolizable protein requirement of a $20-\mathrm{kg}$ BW animal gaining $200 \mathrm{~g} / \mathrm{day}$ is 52.64 g/day: about 34\% lower than the recommended by NRC (2007), of $71 \mathrm{~g} /$ day.

The equation adjusted (Figure 1) between the observed and predicted DMI by the SRNS model was: DMI_obs = -215.29(119.49)+1.21 (0.12)*DMI_pred $\left(\mathrm{r}^{2}=0.85, \mathrm{CV}=8.47\right)$, the hypothesis $\mathrm{H}_{0}$ was not rejected $(\mathrm{P}=0.22)$ and high Pearson's correlation $(r=0.92 ; \mathrm{P}<0.001)$ showed that the model was sensitive in predicting the DMI of growing Santa Ines sheep.

Dry matter intake is the factor with the greatest impact on animal response. Variation in consumption represents

Table 4 - Energy requirements of growing Santa Ines sheep

\begin{tabular}{|c|c|c|c|c|c|c|c|c|}
\hline $\begin{array}{l}\text { Average } \\
\text { daily gain } \\
\text { (g/day) }\end{array}$ & $\begin{array}{l}\mathrm{EBWG}^{2} \\
\text { (g/day) }\end{array}$ & $\begin{array}{c}\text { Net energy } \\
\text { maintenance }^{3} \\
\text { (Mcal/day) }\end{array}$ & $\begin{array}{l}\text { Net energy } \\
\text { gain } \\
\text { (Mcal/day) }\end{array}$ & $\begin{array}{c}\text { Metabolizable energy } \\
\text { maintenance } \\
\text { (Mcal/day) }\end{array}$ & $\begin{array}{c}\text { Metabolizable } \\
\text { energy gain } 5 \\
\text { (Mcal/day) }\end{array}$ & $\begin{array}{c}\text { Total } \\
\text { metabolizable energy } \\
\text { (Mcal/day) }\end{array}$ & $\begin{array}{c}\text { Digestible } \\
\text { energy } \\
\text { (Mcal/day) }\end{array}$ & $\begin{array}{c}\text { Total } \\
\text { digestible nutrients } \\
\text { (g/day) }\end{array}$ \\
\hline \multicolumn{9}{|c|}{15 kg BW (12.06 kg EBW) ${ }^{1}$} \\
\hline 100 & 81 & 0.398 & 0.238 & 0.568 & 0.558 & 1.127 & 1.374 & 0.312 \\
\hline 150 & 121 & 0.398 & 0.357 & 0.568 & 0.838 & 1.406 & 1.714 & 0.389 \\
\hline 200 & 162 & 0.398 & 0.476 & 0.568 & 1.117 & 1.685 & 2.055 & 0.466 \\
\hline 250 & 202 & 0.398 & 0.595 & 0.568 & 1.396 & 1.964 & 2.395 & 0.543 \\
\hline \multicolumn{9}{|c|}{20 kg BW (16.07 kg EBW) ${ }^{1}$} \\
\hline 100 & 81 & 0.494 & 0.278 & 0.705 & 0.652 & 1.357 & 1.655 & 0.375 \\
\hline 150 & 121 & 0.494 & 0.417 & 0.705 & 0.978 & 1.684 & 2.053 & 0.466 \\
\hline 200 & 162 & 0.494 & 0.556 & 0.705 & 1.305 & 2.010 & 2.451 & 0.556 \\
\hline 250 & 202 & 0.494 & 0.695 & 0.705 & 1.631 & 2.336 & 2.849 & 0.646 \\
\hline \multicolumn{9}{|c|}{25 kg BW (20.09 kg EBW) ${ }^{1}$} \\
\hline 100 & 81 & 0.584 & 0.314 & 0.834 & 0.736 & 1.569 & 1.914 & 0.434 \\
\hline 150 & 121 & 0.584 & 0.471 & 0.834 & 1.104 & 1.937 & 2.363 & 0.536 \\
\hline 200 & 162 & 0.584 & 0.627 & 0.834 & 1.472 & 2.305 & 2.811 & 0.638 \\
\hline 250 & 202 & 0.584 & 0.784 & 0.834 & 1.840 & 2.673 & 3.260 & 0.739 \\
\hline \multicolumn{9}{|c|}{30 kg BW (24.11 kg EBW) ${ }^{1}$} \\
\hline 100 & 81 & 0.669 & 0.346 & 0.956 & 0.812 & 1.768 & 2.156 & 0.489 \\
\hline 150 & 121 & 0.669 & 0.519 & 0.956 & 1.218 & 2.174 & 2.651 & 0.601 \\
\hline 200 & 162 & 0.669 & 0.692 & 0.956 & 1.624 & 2.580 & 3.146 & 0.714 \\
\hline 250 & 202 & 0.669 & 0.865 & 0.956 & 2.030 & 2.986 & 3.641 & 0.826 \\
\hline
\end{tabular}

${ }^{1} \mathrm{EBW}=0.8036 * \mathrm{BW} ;{ }^{2}$ Empty body weight gain $=0.8077 * \mathrm{ADG} ;{ }^{3} \mathrm{NEm}=61.49 \mathrm{Kcal} / \mathrm{kg} \mathrm{EBW}{ }^{0.75} / \mathrm{day} ;{ }^{4} \mathrm{~km}=0.70 ;{ }^{5} \mathrm{~kg}=0.43$. 
Table 5 - Protein requirement of growing Santa Ines sheep

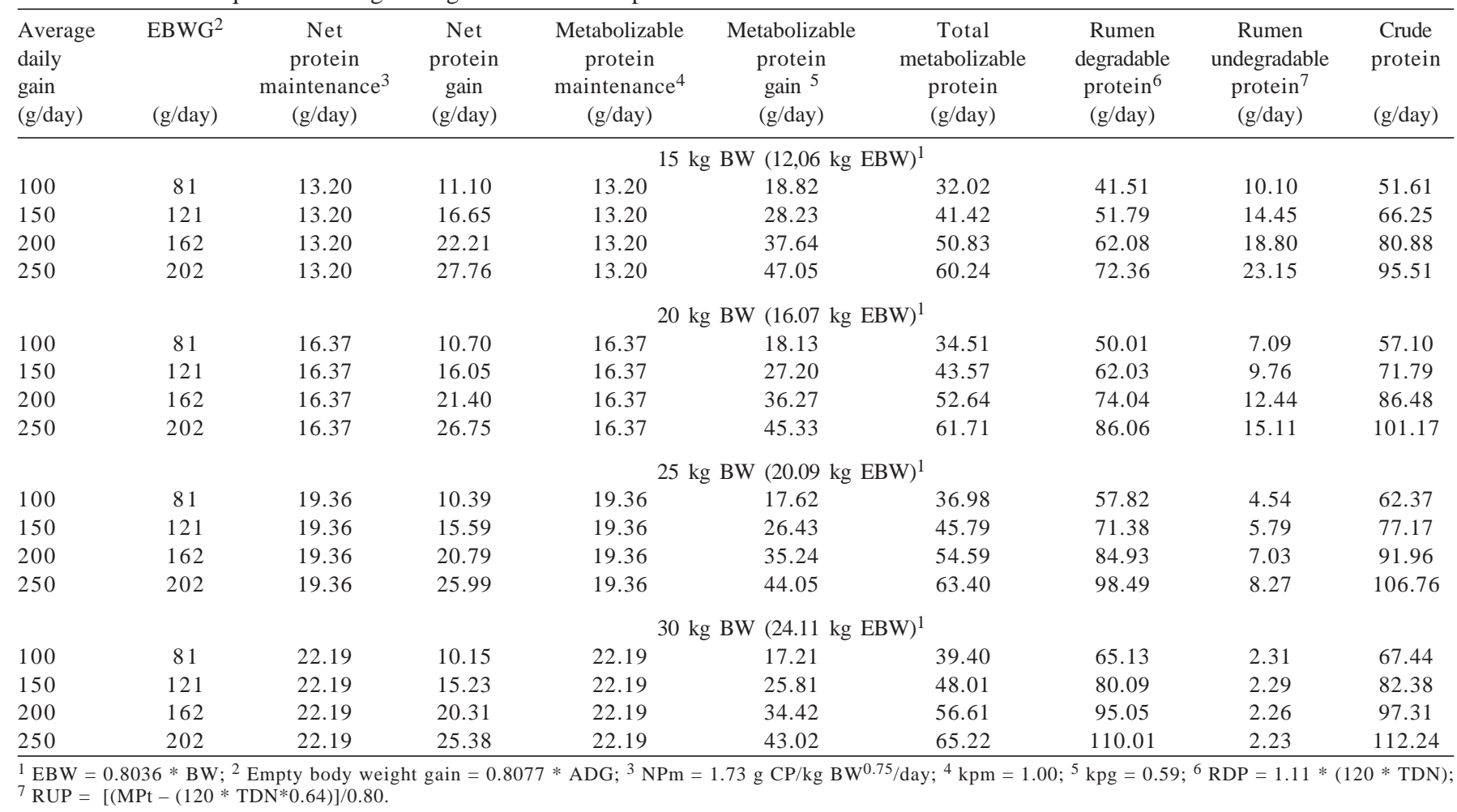

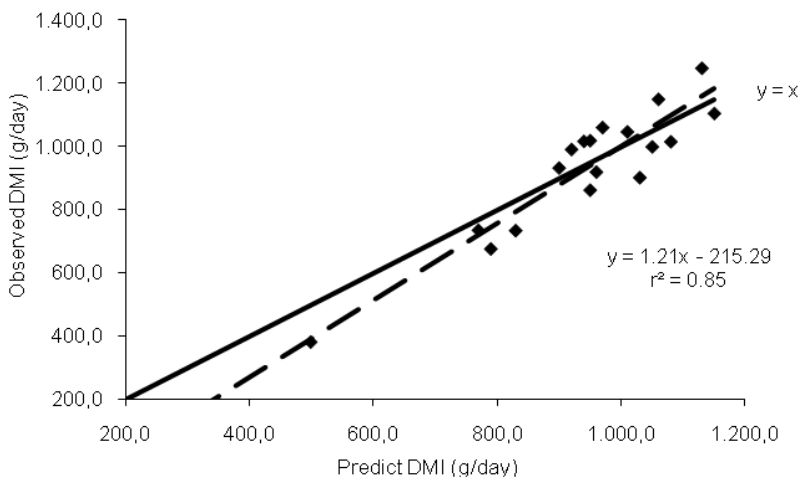

Figure 1 - Relationship between observed dry matter intake and dry matter intake predicted by the model SRNS in growing Santa Ines sheep.

the largest part of the difference in weight gain or milk production in dairy cattle (Poppi, 2008). Thus, different approaches and methodologies are used to predict animal intake, and empirical models are the most widely used due to their greater use simplicity, easy statistical treatment and better representation of animal behavior. However, with the advance of research in the nutrition field, better understanding of the mechanisms controlling intake, especially in the physical aspects and advances in mathematical and statistical treatment given to the phenomena of feed degradation and passage, the trend of using mechanistic models shows to be valid and promising.
The SRNS model showed high precision on the ADG $(r=0.86 ; \mathrm{P}<0.001)$, however, non-accepting of the null hypothesis $(\mathrm{P}<0.001)$ in adjusted linear regression (Figure 2) between the predicted and observed ADG. The fitted equation was: ADG_obs $=59.37(10.79)+0.47(0.07) *$ ADG_pred $\left(r^{2}=0.73, C V=12.90\right)$. The SRNS system simulation overestimated in general ADG at $5.18 \%$.

Apparently, the SRNS model tends to overestimate the ADG at higher gain rates ( $>115 \mathrm{~g} /$ day) and to underestimate it in smaller gain rates ( $<115 \mathrm{~g} /$ day) (Figure 2 ), which may be related to lower efficiency of metabolizable energy utilization for weight gain observed in diets with higher concentration

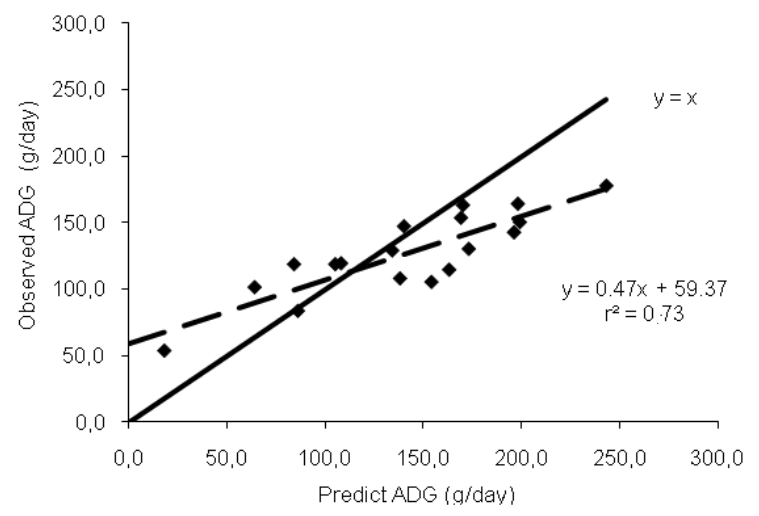

Figure 2 - Relationship between average daily gain of observed body weight and body weight predicted by the model SRNS in Santa Ines growing sheep. 
of metabolizable energy (Table 3). Regadas Filho (2011b) observed a linear increase in ADG with the increase of concentration of metabolizable energy of diets used in this study, but, the average ADG of the diet with a higher concentration of metabolizable energy (2.69 Mcal $/ \mathrm{kg}$ DM and roughage:concentrate relation of 37.5:62.5) was only $161.76 \mathrm{~g} /$ day, demonstrating the low feed efficiency of the animals.

The differences between the prediction of ADG by SRNS and the observed one can be explained also in part by variations in nutritional requirements of animals (Galvani et al., 2008). Besides, SRNS adopts an increase of $15 \%$ in the net energy requirements for maintenance for ram or billy, which increases the magnitude of the responses.

There are not many studies that evaluate models like the SRNS in woolless sheep reared in Brazilian conditions, unlike the bovine species, in which there is more collection of publications evaluating these models. In sheep, there is the need that, from larger databases, models developed under different conditions from those found in Brazil be more accurately and precisely evaluated.

\section{Conclusions}

The lowest values observed for protein requirements compared with those recommended by the National Research Council (2007) corroborate with the assertion that there are differences between the nutritional needs of Santa Ines sheep raised in a semiarid region, and the wool animals typically used in systems of feed and nutritional requirement assessment. The efficiency of metabolizable energy for maintenance and gain is similar to the main systems of nutritional requirements. The Small Ruminant Nutrition Systems model is sensible for predicting dry matter intake in Santa Ines sheep, but it overestimates the average daily gain.

\section{References}

AGRICULTURAL AND FOOD RESEARCH COUNCIL - AFRC. Energy and protein requeriments of ruminants. Wallingford: Commonwealth Agricultural Bureaux International, 1993. 159p.

ALVES, K.S.; CARVALHO, F.F.R.; VÉRAS, A.S.C. et al. Exigências de energia para mantença e eficiência de utilização da energia metabolizável para mantença e ganho de peso de caprinos Moxotó. Revista Brasileira de Zootecnia, v.37, n.8, p.1475-1482, 2008.

CANNAS, A.; TEDESCHI, L.O.; FOX, D.G. et al. A mechanistic model for predicting the nutrient requirements and feed biological values for sheep. Journal of Animal Science, v.82, n.1, p.149-169, 2004

GALVANI, D.B.; PIRES, C.C.; KOZLOSKI, G.V. et al. Energy requirements of Texel crossbred lambs. Journal of Animal Science, v.86, p.3480-3490, 2008.
GARRETT, W.N. Factors influencing energetic efficiency of beef production. Journal of Animal Science, v.51, n.6, p.1434-1440, 1980.

GEAY, Y. Energy and protein utilization in growing cattle. Journal of Animal Science, v.58, n.3, p.766-778. 1984.

HALL, M.B. Calculation of non-structural carbohydrate content of feeds that contain non-protein nitrogen. Gainesville: University of Florida, 2000. P.A-25 (Bulletin, 339).

HARRIS, L.F. Nutrition research techniques for domestics and wild animals. Utah: Logan, v.1. 1970.

LICITRA, G.; HERNANDES, T.M.; Van SOEST, P.J. Standardization of procedures for nitrogen fractionation of ruminants feeds. Animal Feed Science and Technology, v.57, p.347-358, 1996.

MARCONDES, M.I.; GIONBELLI, M.P.; VALADARES FILHO, S.C. et al. Exigências nutricionais de proteína para bovinos de corte. In: VALADARES FILHO, S.C.; MARCONDES, M.I.; CHIZZOTTI, M.L. (Eds.) Exigências nutricionais de zebuínos puros e cruzados: BR-corte. 2.ed. Viçosa, MG: UFV, DZO, 2010. 193p.

MERTENS, D.R. Gravimetric determination of amylase-treated neutral detergent fiber in feeds with refluxing beakers or crucibles: collaborative study. Journal of AOAC International, v.85, p.1217-1240, 2002.

NATIONAL RESEARCH COUNCIL - NRC. Nutrient requirements of beef cattle. 7.ed. Washington, D.C., 1996. 242p.

NATIONAL RESEARCH COUNCIL - NRC. Nutrient requirements of sheep. 6.ed. Washington, D.C.: National Academy Press, 1985. 99p.

NATIONAL RESEARCH COUNCIL - NRC. Nutrient requirements of small ruminants. Washington, D.C.: National Academy Press., 2007. 362p.

POPPI, D.P. The dilemma in models of intake regulation: Mechanistic or empirical. In: FRANCE, J; KEBREAB, E. (Eds). Mathematical modeling in animal nutrition. Wallingford: CAB International, 2008. p.121-141.

REGADAS FILHO, J.G.L.; PEREIRA, E.S.; PIMENTEL, P.G. et al. Body composition and net energy requirements for Santa Ines lambs. Small Ruminant Research, 2011a. (Submitted for publication).

REGADAS FILHO, J.G.L.; PEREIRA, E.S.; VILLARROEL, A.B.S et al. Composição corporal e exigências líquidas proteicas de ovinos Santa Inês em crescimento. Revista Brasileira de Zootecnia, v.40, n.6, p.1339-1346, 2011b.

SILANIKOVE, N. The physiological basis of adaptation in goats to harsh environments. Small Ruminant Research, v.35, p.181-193, 2000

SILVA, D.J.; QUEIROZ, A.C. Análise de alimentos (métodos químicos e biológicos). 3.ed. Viçosa, MG: Universidade Federal de Viçosa, 2002. 235p.

SNIFFEN, C.J.; O'CONNOR, D.J.; VAN SOEST, P.J. et al. A net carbohydrate and protein system for evaluating cattle diets: carbohydrate and protein availability. Journal of Animal Science, v.70, n.11, p.3562-3577, 1992.

TEDESCHI, L.O.; CANNAS, A.; FOX, D.G. A nutrition mathematical model to account for dietary supply and requirements of energy and nutrients for domesticated small ruminants: the development and evaluation of the Small Ruminant Nutrition System. Revista Brasileira de Zootecnia, v.37, p.178-190, 2008.

TEDESCHI, L.O.; FOX, D.G.; RUSSELL, J.B. Accounting for the effects of a ruminal nitrogen deficiency within the structure of the Cornell net carbohydrate and protein system. Journal of Animal Science, v.78, p.1648-1658, 2000

WEISS, W.P. Energy prediction equations for ruminant feeds. In CORNELL NUTRITION CONFERENCE FOR FEED MANUFACTURERS, 61., 1999, Ithaca. Proceedings... Ithaca: Cornell University, 1999. 